\title{
STUDIES ON NEOTROPICAL PHASMATODEA XV: A REMARKABLE NEW \\ STICK INSECT FROM HIGHLY MONTANE HABITATS OF HISPANIOLA (PSEUDOPHASMATIDAE: XEROSOMATINAE: HESPEROPHASMATINI)
}

\author{
Oskar V. Conle ${ }^{1}$, Frank H. Hennemann ${ }^{2}$ and Daniel E. Perez-Gelabert ${ }^{3}$ \\ ${ }^{1}$ Am Freischütz 16, 47058 Duisburg, Germany. conle@phasmatodea.com \\ ${ }^{2}$ Reiboldstrasse 11,67251 Freinsheim, Germany. hennemann@phasmatodea.com \\ ${ }^{3}$ Integrated Taxonomic Information System (ITIS) and Department of Entomology, United States \\ National Museum of Natural History, Smithsonian Institution, Washington, DC 20013-7012. \\ perezd@si.edu. Website: www.phasmatodea.com
}

\begin{abstract}
The new genus and new species Tainophasma monticola gen. nov., sp. nov., a highly montane taxon which is remarkable for its very small size, compact body, short legs and proportionally very large head, is described and illustrated from both sexes and the egg.

Keywords: Stick insects, Phasmatodea, Pseudophasmatidae, Xerosomatinae, Hesperophasmatini, Hispaniola, Dominican Republic, new genus, new species, descriptions, eggs.
\end{abstract}

Título: Estudios sobre Phasmatodea neotropicales XV: un excepcional nuevo insecto palo de hábitats de alta montaña de La Hispaniola (Pseudophasmatidae: Xerosomatinae: Hesperophasmatini).

\section{RESUMEN}

Se describe e ilustra, a partir de ambos sexos y el huevo, el nuevo género y la nueva especie Tainophasma monticola, un taxon de montañas altas excepcional por su pequeño tamaño, cuerpo compacto, patas cortas y cabeza proporcionalmente muy grande.

Palabras clave: mariapalitos, Phasmatodea, Pseudophasmatidae, Xerosomatinae, Hesperophasmatini, Hispaniola, República Dominicana, nuevo género, nueva especie, descripciones, huevos.

\section{INTRODUCTION}

The phasmid fauna of the Greater Antilles is by far richer and more diverse than supposed previously. This became particularly obvious by the investigation of extensive material at hand from the island of Hispaniola. A survey of the Hispaniolan orthopteroid insects was carried out by the Hispaniolan Orthopteroids Project from 2002 through 2004, which comprised eight international expeditions and collections at as many as 280 sites distributed throughout the area of the Dominican Republic. Besides many interesting Orthoptera, large numbers of Phasmatodea were collected, which multiply the number of species known from Hispaniola. In particular the higher elevations of the island still harbor many so far unrecognized taxa, one of which is described in the present paper. Two previous papers by the authors have already dealt with the material collected by the Hispaniolan Orthopteroids Project and described eight new species (Conle, Hennemann and Perez-Gelabert, 2006; Conle, Hennemann and Perez-Gelabert, 2008).

The new genus and species described herein is remarkable for its very small size, compact body, short legs and proportionally very large head. Although it keys out to belong to the Hesperophasmatini Bradley and Galil, 1977, currently regarded a tribe of Pseudophasmatidae: 
Xerosomatinae (Otte and Brock, 2005), the true relationships remain questionable and warrant more extensive investigation of other closely related but as yet undescribed taxa from throughout Hispaniola, which will be subject of forthcoming publications dealing with the extensive material at hand.

Abbreviations used. USNM: United States National Museum of Natural History, Smithsonian Institution, Washington, D. C., USA. MTEC: University of Montana Entomological Collection, Bozeman, Montana, USA. HT, PT: holotype, paratype.

\section{OBJECTIVE}

- To describe a new genus and species of phasmids from the Dominican Republic, Hispaniola.

\section{Tainophasma gen. nov.}

Type species:

Tainophasma monticola sp. nov., by present designation.

Etymology. The Tainos were the original native inhabitants of Hispaniola and some of the other Antillean islands at the arrival of Columbus in 1492. In honour to these people this new genus is named Tainophasma.

Diagnosis of genus. Very small member of the tribe Hesperophasmatini with a stout and robust body, tectiform thorax and short, entirely unarmed legs. Body surface granulated and rugose, not shiny. Head compressed dorsoventrally and very large in relation to body. Eyes small, no ocelli present. Antennae simple, fairly robust and about as long as the fore legs. Thorax very stout and wider than high in cross-section. Mesonotum and metanotum distinctly tectiform. Very small rudiments of tegmina and alae present. Abdomen as long as head and thorax combined, very stout and bulgy in female less stout and not bulgy in male. Subgenital plate of female very large, bulgy and distinctly boat-shaped, the posterior margin rounded and roughly reaching to apex of abdomen. Poculum of male small and flat, posterior margin rounded reaching to posterior margin of tergum IX. Vomer forming an isosceles triangle with a blunt apex. Cerci in both sexes short.

Diagnosis del género. Miembro muy pequeño de la tribu Hesperophasmatini con un cuerpo robusto y grueso, tórax tectiforme y corto, patas inermes. Superficie del cuerpo granulosa y rugosa, no brillante. Cabeza comprimida dorsoventralmente y muy grande en relación al cuerpo. Ojos pequeños, ocelos ausentes. Antenas simples, algo robustas y tan largas como las patas anteriores. Tórax muy compacto y más ancho que alto en sección transversal. Mesonoto y metanoto distinctivamente tectiforme. Pequeños remanentes de las tégminas y alas presentes. Abdomen tan largo como la cabeza y tórax combinados, muy grueso y abultado en la hembra, menos grueso y no abultado en el macho. Placa subgenital de la hembra bien grande, abultada y distintivamente en forma de bote, su margen posterior redondeado y alcanzando el ápice abdominal. Póculo del macho pequeño y aplanado, su margen posterior redondeado y alcanzando el margen posterior del tergito IX. Vómer formando un triángulo isósceles con ápice no agudo. Cercos cortos en ambos sexos.

Description of genus. Very small member of the tribe Hesperophasmatini (body length 933.0 $\mathrm{mm}, \widehat{O} 24.5 \mathrm{~mm}$ ) with a stout and robust body, tectiform thorax and short, entirely unarmed legs. 
Bodysurfacegranulatedandrugose, notshiny, thoraxandheadbearing severalrowsofsmallgranules. Head about $1.5 x$ longer than wide, slightly widening towards posterior, compressed dorsoventrally and very large in relation to body. Vertex flattened with several rows of small granules and a crown-like, elevated structure on frons between the antennae. Eyes small, circular, not projecting over width of head. No ocelli. Antennae simple, fairly robust and about as long as the fore legs. All antennomeres except scapus cylindrical and finely bristled. Scapus hardly longer than wide, oval in dorsal aspect with the lateral margins roundly deflexed, dorsoventrally compressed and more than $2 \mathrm{x}$ longer than pedicellus. Pedicellus cylindrical, hardly longer than wide and much more slender than scapus, but wider than the following segments. Third antennomere as long as scapus.

Thorax granulated and rugose very stout and wider than high in cross-section. Pronotum distinctly shorter, but as wide as head; $2 \mathrm{x}$ wider than long in female and about1.5x wider than long in male; bearing two distinct dorsomedian longitudinal rows of granules. Transverse median sulcus slightly impressed, almost straight and just not spanning entire width of segment. Mesonotum and metanotum distinctly tectiform with a prominent and blunt dorsomedian longitudinal keel. Mesonotum about $2.5 \mathrm{x}$ longer and slightly wider than pronotum and roughly parallel-sided; $2 \mathrm{x}$ longer than wide in female and $2.3 \mathrm{x}$ longer than wide in male; in both sexes with a slightly deflexed longitudinal carina near lateral margins. Metanotum 2x wider than long in female and nearly rectangular in male. Transverse fissure between metanotum and median segment very indistinct. Very small rudiments of tegmina and alae are present. Prosternum with two prominent median granules which possibly constitute sensory areas. Probasisternum prominently rugose. Meso- and metasternum very minutely rugulose, the mesosternum in anterior portion with a very fine longitudinal median carina. Abdomen as long as head and thorax combined, very stout and bulgy in female, less stout and not bulgy in male, constricted towards tergum $\mathrm{X}$, surface rugose, with two prominent dorsomedian longitudinal carinae and two less defined diagonally directed carinae laterally. In female: median segment $4 \mathrm{x}$ wider than long, tergum II the shortest and V the widest segment. VIII the longest segment and noticeably longer than previous. II-VII 5-6x wider than long, VIII 3x and IX 2.5x wider than long. Anal segment with a distinct longitudinal dorsomedian carina, slightly more slender than IX and most slender segment, about $2 \mathrm{x}$ wider than long, the posterior margin straight with the outer angles fairly truncate. Supraanal plate somewhat projecting over posterior margin of anal segment, noticeably wider than long. Sterna bearing two irregular longitudinal rows of rugulae medially and a fairly acute longitudinal carina near lateral margins. Preopercular organ on sternum VII represented by a distinct v-shaped incision, which is laterally framed by two compressed and rounded, spiniform projections. Subgenital plate very large, bulgy and distinctly boat-shaped, the posterior margin rounded and roughly reaching to apex of abdomen. In male: Abdomen parallel sided towards tergum VI. VII-VIII broadened towards posterior, IX and X constricted towards posterior, II-IX 4x wider than long, VIII widest segment. Anal segment about $2.5 \mathrm{x}$ wider than long, posterior margin with a distinct and widely triangular median excavation, the lateral margins roundly deflexed. Poculum small and flat, posterior margin rounded reaching to posterior margin of tergum IX. Vomer forming a isosceles triangle with a blunt apex. Cerci in both sexes short and dorsoventrally flattened, posteriorly rounded and covered with fine bristles. Legs short and robust, distinctly carinated, partly covered with minute setae. Femora almost rectangular in cross-section and with a very fine medioventral carina. Tibiae trapezoidal in cross-section with the dorsal carinae slightly nearing; medioventral carina distinct. Profemora compressed and curved basally. Mesofemora about as long as mesonotum. Basitarsus 1.5-2x longer than second tarsomere. Hind legs (excluding tarsi) roughly reaching apex of abdomen.

Eggs. Only one egg is available, which was removed from the abdomen of the $q$ PT. Hence, the following description should be regarded as provisional. 
Capsule globose and ovoid, about 1.6x longer than wide, slightly laterally flattened and oval in cross-section, dorsal portion strongly convex. Capsule surface covered with minute granules. Micropylar plate elongate and lancet-shaped, widened in posterior half, roughly $3 / 4$ the length of capsule, outer margin weakly raised. Micropylar cup represented by a rounded median swelling placed in the center of the broadest part of micropylar plate near polar end. Median line almost reaching polar area of capsule. Operculum oval and slightly convex; surface strongly and unevenly tuberculose. Opercular angle slightly slanting towards micropylar plate.

Differentiation. In several aspects this new genus is rather apart from all other genera of the tribe Hesperophasmatini Bradley \& Galil, 1977. Although Tainophasma gen. nov. keys out to this tribe, definition of the true relationships needs to await knowledge of several other still undescribed taxa from throughout the island of Hispaniola, which will be subject of future works.

The very small size, compact body, short and robust, entirely unarmed legs and extremely large head in relation to the body at once distinguish Tainophasma gen. nov. from all others of the tribe. At least the small size, compact body and robust legs are however merely adaptions to its highly montane habitat. Hence, only the unarmed extremities, proportionally large head, tectiform thorax and short subgenital plate of $q$, , which does not extend over the apex of the abdomen, appear to be of higher taxonomic relevance. The eggs differ from those of other Hesperophasmatini by lacking any spiniform projections or hairy structures.

\section{Tainophasma monticola sp. nov.}

Figures 1-10

Diagnosis of species. Female: small, stout and compact insects with a heavily bulgy abdomen and tectiform thorax. General colouration of body dull ochre to dark grayish brown with indistinct blackish lines and granules on thorax and abdomen. Ventral surface of body brown to dull ochre. Legs dark-brown with a characteristic pale cream marking on the dorsal and lateral surfaces of each femur. Dorsal surfaces of all tibiae pale cream in the median portion. Male: generally as female, but much more slender and smaller. Colouration mostly as in female.

Diagnosis de la especie. Hembra: insectos pequeños, gruesos y compactos con abdomen abultado y tórax tectiforme. Coloración general del cuerpo ocre no brillante a castaño grisacea oscura con lineas negruzcas indistintas y gránulos sobre tórax y abdomen. Superficie ventral del cuerpo castaño a ocre no brillante. Patas castaño oscuro con características marcas crema claro sobre superficies dorsales y laterales de cada femur. Superficies dorsales de todas las tibias crema claro en su porción media. Macho: en general como la hembra, pero mucho más esbelto y pequeño. Coloración mayormente como en la hembra.

Material examined. HT, §̊: Dominican Republic, RD-048, Top of La Pelona, Parque Nacional Armando, Bermúdez, La Vega Prov., 1901.911'N 7100.339’W, 18.VII.2002, D. Perez, B. Hierro, R. Bastardo (USNM).

PT, 1 q, 1 egg: Dominican Republic, RD-048, Top of La Pelona, Parque Nacional Armando, Bermúdez, La Vega Prov., $19^{\circ} 01.911^{\prime} N$ 7 $1^{\circ} 00.339^{\prime}$ W, 18.VII.2002, D. Perez, B. Hierro, R. Bastardo (USNM).

PT, 5 nymphs: Dominican Republic, RD-076, Down from Cuevita, Valle Nuevo, La Vega Prov., 2096 m, 1846.326’N 7040.438’W, 28.XI.2002, D. Perez, B. Hierro, R. Bastardo, (night) (USNM). 

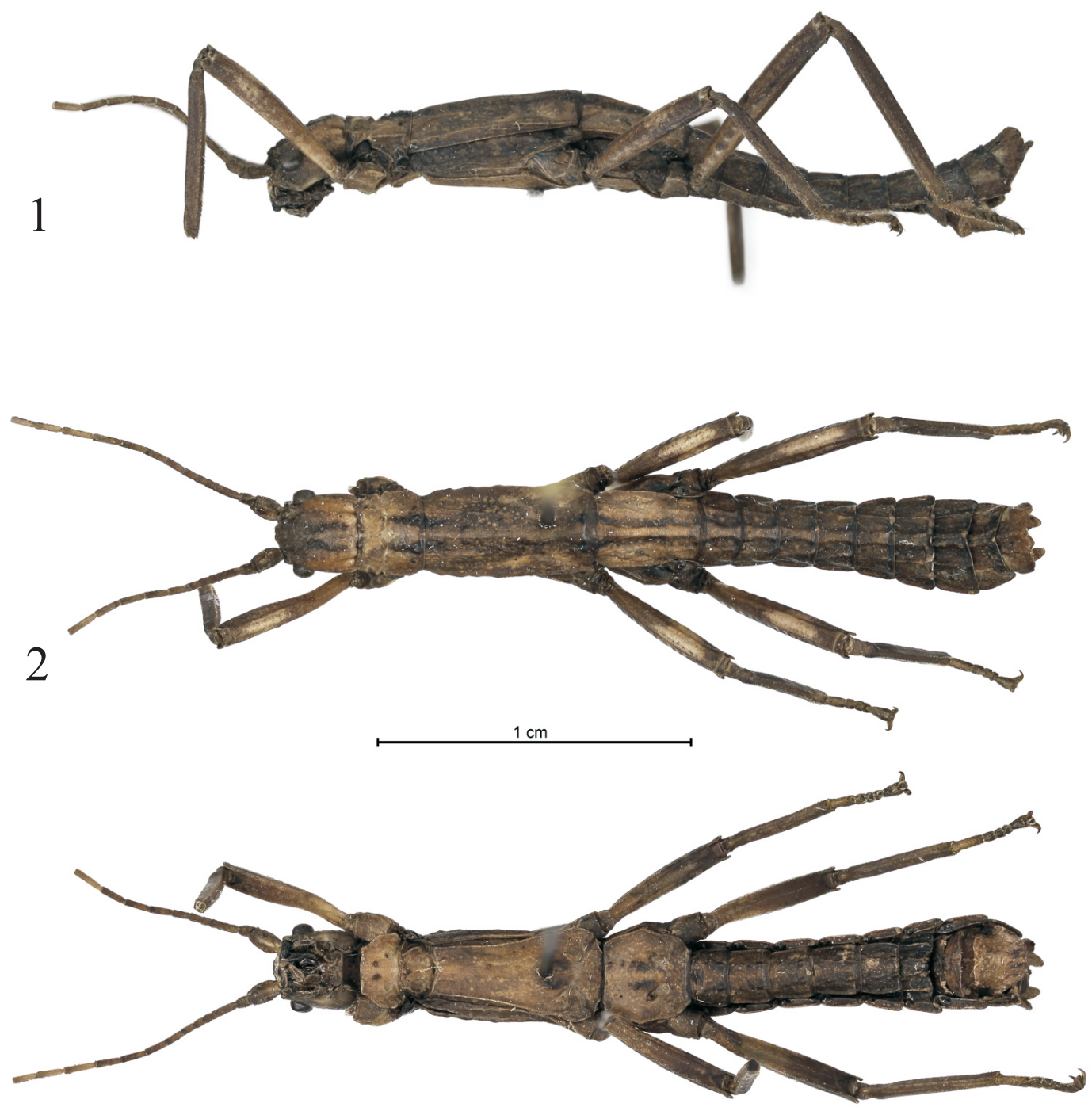

3 

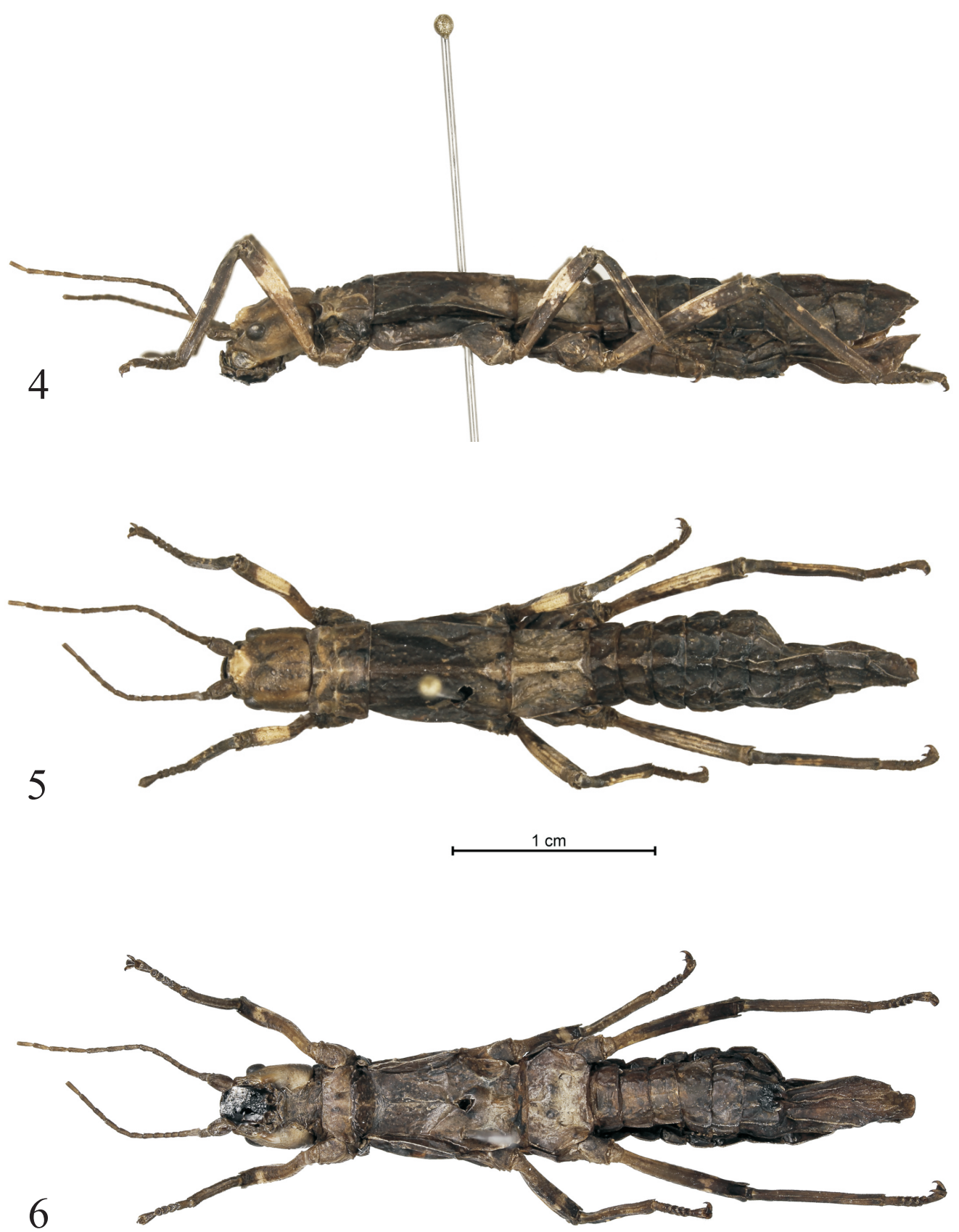

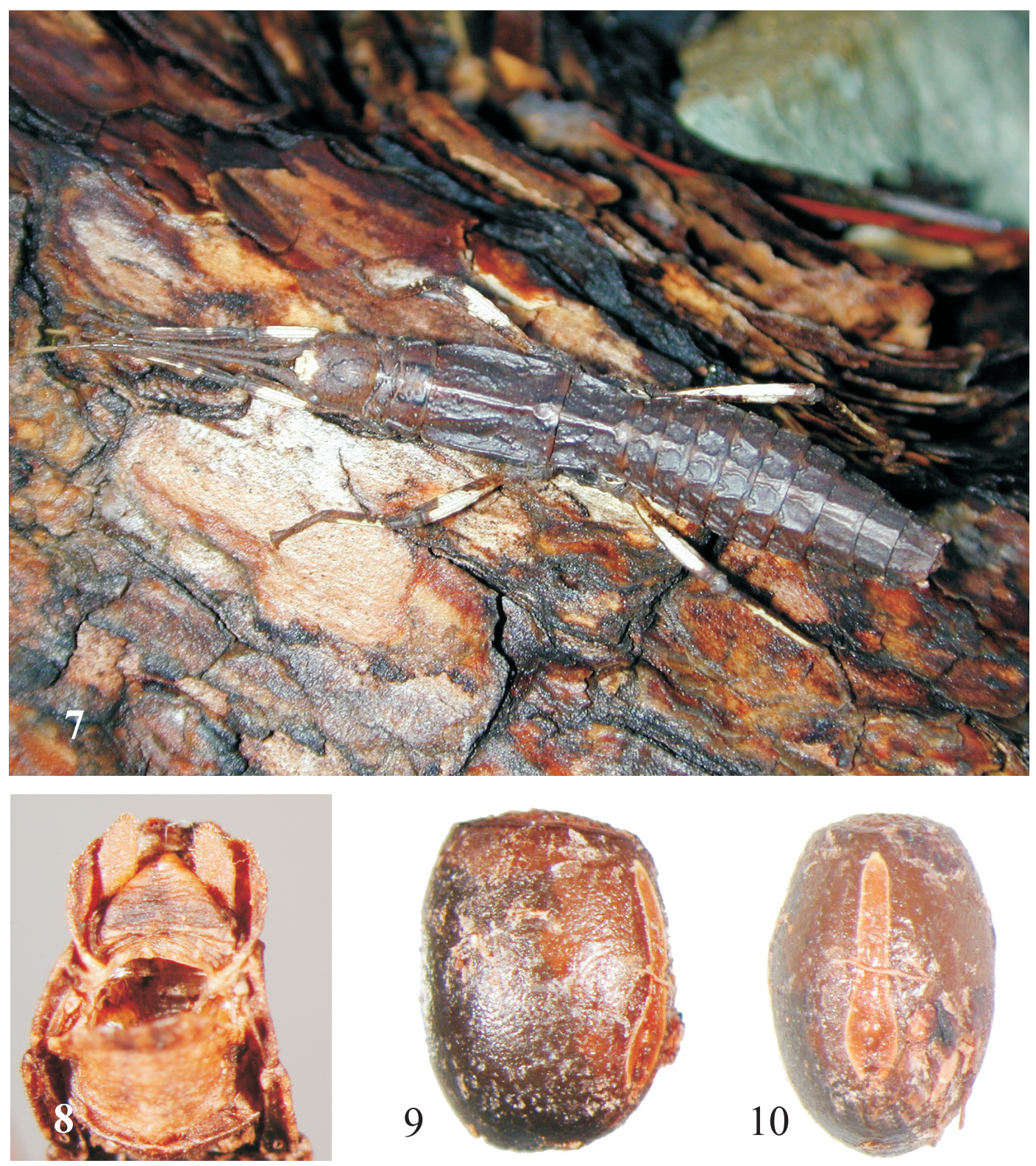

Figure 7: $\rightarrow$ PT live in original habitat walking on a rotting tree.

Figure 8: Vomer of $\lesssim$ HT (USNM).

Figures 9-10: Egg removed from abdomen of $\odot$ PT (USNM). 
PT, 1 nymph: Domin. Rep., Prov. Santiago, Par. Nac. Armando Bermúdez, summit of La Pelona, 09. July 1992, under rocks, 3087m, M.A. \& R.O., Ivie (MTEC).

Distribution. Hispaniola: Dominican Republic: La Vega Province and Santiago Province. This small species is obviously adapted to very high, montane habitats between 2000 to 3100 meters above sea-level. The paratype $q$ specimen was collected from the top of a wet, decaying log lying on the ground under pine trees early at night.

Etymology. This new species is named monticola due to its distribution in the high mountains of Hispaniola.

Species description. For morphological details see description of the genus above. Female: small (body length $33.0 \mathrm{~mm}$ ), stout and compact insects with a heavily bulgy abdomen and tectiform thorax. Head ochre to light brown; crown-like structure on frons. Antennae uniformly brown. Eyes dark brown. General colouration of body dull ochre to dark grayish brown with indistinct blackish lines and granules on thorax and abdomen. Ventral surface of body brown to dull ochre. Cerci uniformly brown. Legs dark-brown with a characteristic pale cream marking on the dorsal and lateral surfaces of each femur. Dorsal surfaces of all tibiae pale cream in the median portion. Male: generally as female, but much more slender and smaller (body length $24.5 \mathrm{~mm})$. Colouration mostly as in female.

Measurements. 9 (PT, USNM): body length 33.0; pronotum 3.0; mesonotum 7.0; metanotum 2.2; median segment 1.8; profemora 6.7; mesofemora 5.9; metafemora 8.2 ; protibiae 6.2; mesotibiae 5.9; metatibiae 8.3; antennae 14.0. 万( (HT, USNM): body length 24.5; pronotum 2.1; mesonotum 5.4; metanotum 2.2; median segment 1.6; profemora 5.7; mesofemora 5.2; metafemora 6.7; protibiae 6.0; mesotibiae 5.3; metatibiae 7.1 ; antennae $>10.0$.

Egg. See description above. General colour dark reddish brown, micropylar plate pale reddish brown with the outer margin ochre. Measurements: length $3.4 \mathrm{~mm}$; width $2.0 \mathrm{~mm}$; height 2.5 $\mathrm{mm}$; length of micropylar plate $2.2 \mathrm{~mm}$.

\section{ACKNOWLEDGEMENTS}

Thanks are due to all the Dominican biologists that contributed to the successful expeditions of the Hispaniolan Orthopteroids Project (Ruth H. Bastardo, Brígido Hierro, Sardis Medrano, Denia Veloz, Litay Ramos, Juana Peña and others). Dr. Michael Ivie (University of Montana) made us aware of this species by loaning DEPG a specimen he collected. Our thanks also to Karolyn Darrow (Department of Entomology, Smithsonian Institution) for taking the excellent pictures presented in this paper. The Ministerio de Medio Ambiente y Recursos Naturales (then Secretaría) en Santo Domingo, graciously provided our collecting and export permits.

\section{LITERATURE CITED}

Bradley, J. C. and B. S. Galil. 1977. The taxonomic arrangement of the Phasmatodea with keys to the subfamilies and tribes. Proceedings of the Entomological Society of Washington, 79: 176-208.

Conle, O. V., F. H. Hennemann andD. E. Perez-Gelabert. 2006. Studies on neotropical Phasmatodea III: A new species of Anisomorpha Gray, 1835 (Phasmatodea, Pseudophasmatidae, Pseudophasmatinae) from Hispaniola. Proceedings of the Entomological Society of Washington, 108: 885-891. 
Conle, O. V., F. H. Hennemann and D. E. Perez-Gelabert. 2008. Studies on neotropical Phasmatodea II: Revision of the genus Malacomorpha Rehn, 1906, with the descriptions of seven new species (Phasmatodea: Pseudophasmatidae: Pseudophasmatinae). Zootaxa, 1748: 1-64.

Otte, D. and P. Brock. 2005. Phasmid Species File. Catalog of Stick and Leaf Insects of the World, $2^{\text {nd }}$ Edition. The Insect Diversity Association and the Academy of Natural Sciences, Philadelphia. CafePress.com, 414 pp.

[Recibido: 28 de abril, 2014. Aceptado para publicación: 13 de agosto, 2014] 